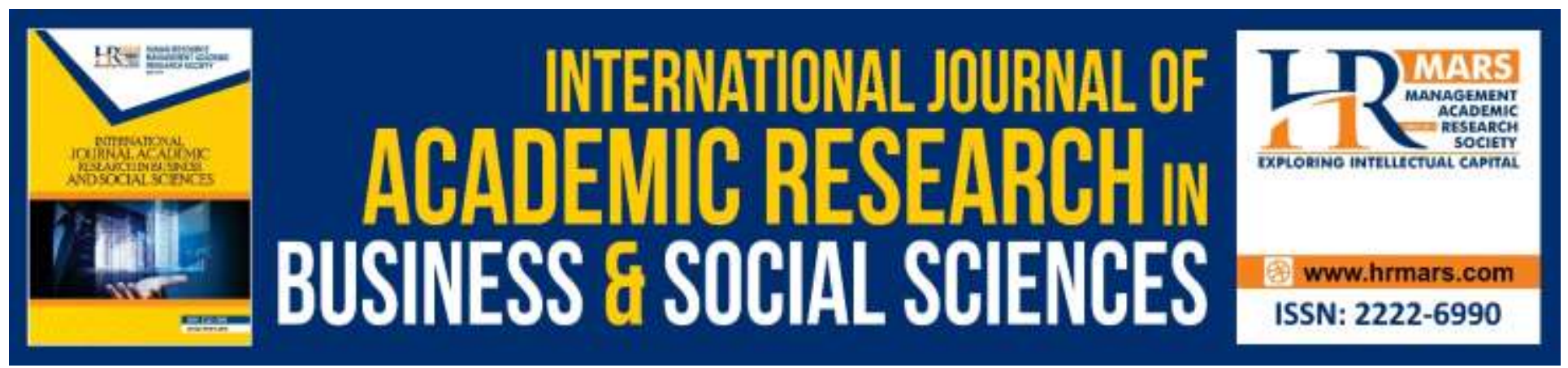

\title{
Motivation and its Relationship towards The Achievement in Quranic Memorisation of Tahfiz School Students in Pahang
}

Mohd Saleh Bin Ramli \& Syed Sofian Syed Salim

To Link this Article: http://dx.doi.org/10.6007/IJARBSS/v10-i5/7252

DOI:10.6007/IJARBSS/v10-i5/7252

Received: 25 March 2020, Revised: 29 April 2020, Accepted: 03 May 2020

Published Online: 28 May 2020

In-Text Citation: (Ramli \& Salim, 2020)

To Cite this Article: Ramli, M. S. Bin, \& Salim, S. S. S. (2020). Motivation and its Relationship towards The Achievement in Quranic Memorisation of Tahfiz School Students in Pahang. International Journal of Academic Research in Business and Social Sciences, 10(5), 822-829.

Copyright: (C) 2020 The Author(s)

Published by Human Resource Management Academic Research Society (www.hrmars.com)

This article is published under the Creative Commons Attribution (CC BY 4.0) license. Anyone may reproduce, distribute, translate and create derivative works of this article (for both commercial and non-commercial purposes), subject to full attribution to the original publication and authors. The full terms of this license may be seen at: http://creativecommons.org/licences/by/4.0/legalcode

Vol. 10, No. 5, 2020, Pg. 822 - 829

http://hrmars.com/index.php/pages/detail/IJARBSS

JOURNAL HOMEPAGE

Full Terms \& Conditions of access and use can be found at http://hrmars.com/index.php/pages/detail/publication-ethics 


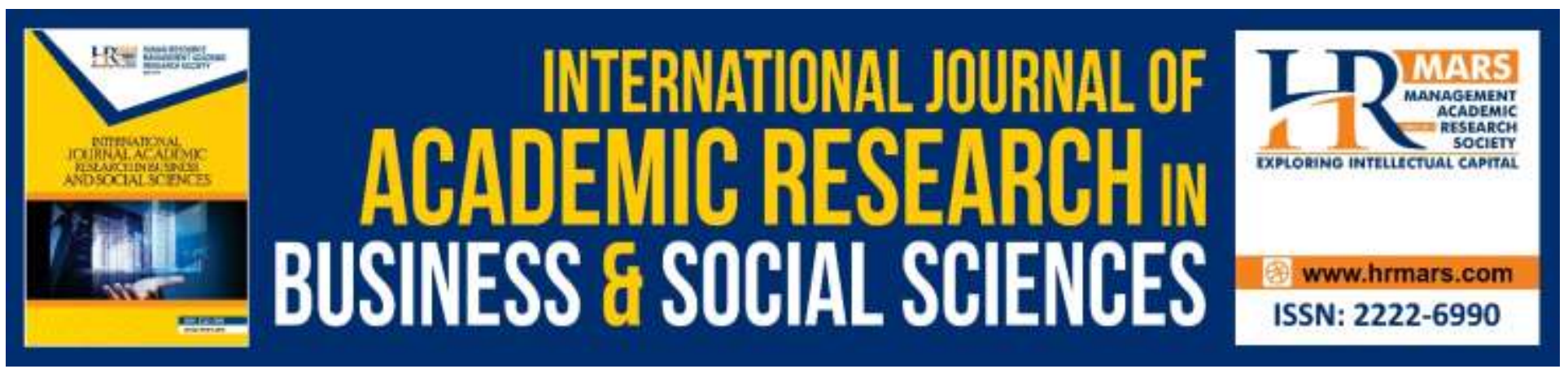

\title{
Motivation and its Relationship towards The Achievement in Quranic Memorisation of Tahfiz School Students in Pahang
}

\author{
Mohd Saleh Bin Ramli \& Syed Sofian Syed Salim \\ Faculty of Education and Human Development, Sultan Idris Education University.
}

\begin{abstract}
The purpose of this research is to analyse the relationship between motivation and its relationship towards the achievement in Quranic memorisation of Tahfiz school students in Pahang. This research has employed the method of survey where samples were chosen using stratified random sampling involving 254 students from 4 Tahfiz schools in Pahang. The instrument used to measure students' motivation is the Work Preference Inventory (WPI), while students' Quranic memorisation achievements are measured through their Al-Quran examination score. The data was analysed using the SPSS software version 23. The result of this analysis, which has used Pearson correlation, has shown that there is a positively significant relationship between motivation and Quranic memorisation achievements $(r=0.291, p<.05)$. Meanwhile, the ANOVA two-ways analysis of the data has found that there is a significant interaction between motivation and Quranic memorisation achievements from the aspects of age $[F=1.452 ; p=0.031]$, place of origin [ $F=1.950 ; p=0.007]$. In light of these results, it warrants the need for schools, District Education Office (PPD), District Education Department (JPN) and Ministry of Education (MOE) in general to improvise the memorisation module while taking into account the previously said variables in order to improve the achievement in Quranic memorisation among students.
\end{abstract}

Keyword: Motivation, Achievement in Quranic Memorisation.

\section{Introduction}

Motivation means an unyielding or strong desire in a person that motivates him or her to strive or to do something with the aims of achieving success. In addition, motivation also means something that motivates or pushes someone to try or do something with full interest. The definition is in line with Latin language by the word "movere" which means to move as David (2012) has stated. This is because a motivated person will move on to do and make what he or she wants a reality.

According to Saleh (2014), there are two types of motivations namely intrinsic motivation and extrinsic motivation. Intrinsic motivation is an internal motivation that arises out of curiosity and is intended to satisfy self-gratification. Whereas the extrinsic motivation is an external motivation which rose from external influences. The effects of such motivations will give way for actions to 
INTERNATIONAL JOURNAL OF ACADEMIC RESEARCH IN BUSINESS AND SOCIAL SCIENCES

Vol. 10, No. 5, May, 2020, E-ISSN: 2222-6990 ㄷ 2020 HRMARS

achieiive its objectives (Arif, 2013). Purwanto (2014) states that motivation is not just a process of generating action, it is also more so that a motivated person will try to defend his will and his goals. Without a strong motivation, students' enthusiasm for success will fade thus causing them to fail in Al-Quran.

\section{Problem Statement}

Memorizing the Al-Quran requires high commitment, however due to low level of Motivation, only a few students have succeeded in doing so. A research by Azmil, Abdul Halim dan Misnan (2013) on 11 Tahfiz schools across the Malaysian states have found that $60 \%$ of these students have failed to complete their memorisation within the period of 6 semesters. That is also the case when Norizah (2014) discovered in her research on pre-school students that $56 \%$ of respondents have failed to memorise the quranic chapters and siupplications that were set in the syllabus. Nor Musliza (2015) concludes that because memorisation of the Quran requires a high level of commitment, only a few of these students were successful in memorising it.

\section{Objectives of Study}

This thesis is to analyses

- The relationship between Motivation on the performance of Al-Quran memorization of Tahfiz school students in Pahang.

- This research also measures the interaction between Motivation on the performance of AlQuran memorization based on gender, age, place of origin, parents' educational background and parents' income.

\section{Literature Review}

(a) Motivation

There exist many theories on motivation including Maslow's motivation theory, McClelland's motivation theory, Alderfer's motivation theory and Herzberg's motivational theory. According to San and Higgins (2013), the motivational theory developed by Maslow (1954) is centered on selffulfillment. He divided the level of these needs into five: (1) physiological needs such as hunger, thirst, sleep and so on. (2) Mental and physical safety needs. (3) Love needs is where they want to be loved and loved. (4) Self-esteem needs that is valued by respect, position, status and so on. (5)Selfactualization is the development of the potential self so that it becomes a real ability.

According to Arif (2013), a person's level of motivation varies according to the strength of the need. The higher the goal, the higher the motivation level (Purwanto, 2014). A student needs to realise the need of success in order to feel the motivation that drives him or her to actually succeed. According to Siti Suminarti Fasikhah (2013), motivation rises because of two factors, namely internal factors and external factors. Internal factors provide more motivation than external factors. Ahmad Rozaini Ali Hasan (2017) in his study found that there is a link between motivation and achievement of the Quran.

\section{(b) Quranic Memorisation}

Quranic Memorisation is a process by which one memorises the Holy Book of Islam through reading it repeatatively to transfer those facts into the working memory and to the long-term memory, via 
various techniques. The study of the memorisation of the Quran links closely to theories available in cognitive studies and psychology. According to Khazriyati Salehuddin (2019), amongst the psychological theories that could relate to techniques in Quranic memorisation is the chunking technique in theories of the working memory by Miller (1956), the repeatition technique in behavioural theory by Skinner (1957), segmenting technique by Meyer (2001) and more. Meanwhile, in cognitive studies, Quranic memorisation can be linked to Gestalt Theory, Piaget Theory, Social Learning Theory and the Theory of Meaningful Learning that was founded by renowed psychologists such as Professor Dr. Koffka, Professor Dr. Kohler, Professor Dr.Bruner, Professor Dr. Albert Bandura, Professor Dr. Gagne, Professor Dr. David Ausuble and others.

According to Khalid (2016), tahfiz schools that applies the Intergrated Tahfiz Curriculum (Kurikulum Bersepadu Tahfiz) or Tahfiz Model Ulul Albab (TMUA), have set their memorisation goals by dividing them yearly. The syllabus of as much as 30 Juzu' of the Quran is divided into five years of study; six Juzu' in form one, seven Juzu' in form two, six Juzu' in form three, seven Juzu' in form four and four Juzu' in form five.

The process of memorising starts in Tahdir class where students undergo an activity that entails them to repeat the new verses they are about to memorise as a preparation for the Tasmi' class. This class starts at 6.30 in the morning until 7.10 in the morning. Students will check and strengthen the new verses by reciting them in front of a teacher individually as preparation before Tasmi' activities commences, with the ratio of one teacher to ten students. After the Tahdir class, students will continue the memorisation process in Tasmi' class and Muraja'ah starting 7.30 to 9.30 in the morning. Tasmi' class in an activity where new Quranic verses are recited in front of a teacher individually, while Muraja'ah is an activity where those newly recited verses are repeated in front of the same teacher individually.

The two-hour class period is divided into three activities; tasmi' of one new page starting at 7.30 to 8.10 in the morning, repeated memorisation of two pages starting at 8.10 to 8.50 in the morning and repeated memorisation of previous verses at 8.50 to 9.30 in the morning. After the Quranic memorisation class,students will continue on with their academic classes from 10 am to 4.30 in the evening. At night from 7.30 to $8.30 \mathrm{pm}$, students are scheduled to follow new memorisation class for it to recited in front of the teacher again the next day.

\section{Methodology}

This research has employed the method of survey where samples were chosen using stratified random sampling involving 254 students from 4 Tahfiz schools in Pahang The instrument used to measure students' Motivation is the Work Preference Inventory (WPI), a 40-item inventory constructed by Amabile (1987).There are four scales that starts from 1 for never to 4 for very always. The score was divided into 3 which are high, medium and low. The score of 81 to 120 is considered to possess high level of motivation. While the score of 41 to 80 is a medium leve of motivation and 1 to 40 is considered as low.

Meanwhile, the students' achievement in memorisation was measured through Quranic examination and is divided into grades that were set by the government. The relationship between these variable was measured using a Pearson correlation analysis, while the interaction between the demographical variables were measured using two-way ANOVA. 
INTERNATIONAL JOURNAL OF ACADEMIC RESEARCH IN BUSINESS AND SOCIAL SCIENCES Vol. 10, No. 5, May, 2020, E-ISSN: 2222-6990 @ 2020 HRMARS

\section{Findings}

The research results are given in table $1-6$. The research findings are presented in two levels of descriptive and inference.

a. Descriptive analysis of the respondent's study

Table 1 : Gender analysis of respondent

\begin{tabular}{lcc}
\hline Gender & Frequency & Percentage \\
\hline Men & 130 & $51.2 \%$ \\
Women & 124 & $48.8 \%$ \\
\hline Total & $\mathbf{2 5 4}$ & $\mathbf{1 0 0 . 0 \%}$ \\
\hline
\end{tabular}

Based on table 1, the number of respondents is 254 people. A total of 130 were men (51.2\%) while 124 were women (48.8.4\%).

Table 2 : Age analysis of respondent

\begin{tabular}{lcc}
\hline Age & Frequency & Percentage \\
\hline Form 1 & 53 & $20.9 \%$ \\
Form 2 & 53 & $20.9 \%$ \\
Form 3 & 49 & $19.3 \%$ \\
Form 4 & 50 & $19.7 \%$ \\
Form 5 & 49 & $19.3 \%$ \\
\hline Total & $\mathbf{2 5 4}$ & $\mathbf{1 0 0 . 0 \%}$ \\
\hline
\end{tabular}

Based on table 2, 20.9\% of them are form 1, 20.9\% of them are form 2, 19.3\% of them are form 3, $19.7 \%$ of them are form 4 and $19.3 \%$ of them are form 5 .

Table 3 : Place origin analysis of respondent

\begin{tabular}{lcc}
\hline Place Origin & Frequency & Percentage \\
\hline City & 173 & $68.1 \%$ \\
Rural Area & 81 & $31.9 \%$ \\
\hline Total & $\mathbf{2 5 4}$ & $\mathbf{1 0 0 . 0 \%}$ \\
\hline
\end{tabular}

Based on table $3,68.1 \%$ of them are from the city while $31.9 \%$ are from rural areas. 
INTERNATIONAL JOURNAL OF ACADEMIC RESEARCH IN BUSINESS AND SOCIAL SCIENCES Vol. 10, No. 5, May, 2020, E-ISSN: 2222-6990 ㄷ 2020 HRMARS

Table 4 : Parental Income analysis of respondent

\begin{tabular}{lcc}
\hline Parental Income & Frequency & Percentage \\
\hline RM 8,001 and upward & 132 & $52.0 \%$ \\
RM 4001 - RM 8,000 & 60 & $23.6 \%$ \\
RM 1001 - RM 4,000 & 54 & $21.3 \%$ \\
Below RM 1,000 & 8 & $3.1 \%$ \\
\hline Total & $\mathbf{2 5 4}$ & $\mathbf{1 0 0 . 0 \%}$ \\
\hline
\end{tabular}

ased on table 4, 3.1\% had household income of below RM 1,000, while $21.3 \%$ had household income between RM 1,001 to RM 4,000, 23.6\% had household income between RM 4,001 to RM 8,000 and $52 \%$ had household income above RM 8,001 and upward.

b. Inference analysis of the respondent's study

Table 5 : The analysis of relationship of Motivation and Quranic Memorisation

\begin{tabular}{|c|c|c|c|c|c|}
\hline \multicolumn{2}{|l|}{ Variable } & $R$ value & \multicolumn{2}{|c|}{ Significant value } & Result \\
\hline \multicolumn{2}{|c|}{$\begin{array}{l}\text { Motivation on Quranic } \\
\text { Memorisation }\end{array}$} & $0.291^{* *}$ & \multicolumn{2}{|c|}{0.000} & $\begin{array}{l}\text { Significant } \\
\text { relationship }\end{array}$ \\
\hline \multicolumn{6}{|c|}{$\begin{array}{l}\text { Based on table } 5 \text {, results from the Pearson correlation analysis showed that motivation had a } \\
\text { correlation with Quranic achievements }(r=0.291, p<0.05) \text {. }\end{array}$} \\
\hline \multicolumn{6}{|c|}{$\begin{array}{c}\text { Table } 6 \text { : The analysis of interaction of Motivation and Quranic Memorisation based on } \\
\text { demographic factors }\end{array}$} \\
\hline $\begin{array}{l}\text { Causes of } \\
\text { Variation }\end{array}$ & $\begin{array}{l}\text { Sum of } \\
\text { Squares }\end{array}$ & df & Mean $^{2}$ & F value & $\begin{array}{l}\text { Significant } \\
\text { value }\end{array}$ \\
\hline Gender & 2703.956 & 26 & 103.998 & 1.344 & 0.135 \\
\hline Age & 8202.829 & 89 & 92.167 & 1.452 & 0.031 \\
\hline $\begin{array}{l}\text { Place of } \\
\text { Origin }\end{array}$ & 3432.474 & 25 & 137.299 & 1.950 & 0.007 \\
\hline $\begin{array}{l}\text { Parental } \\
\text { Income }\end{array}$ & 3720.003 & 46 & 80.870 & 1.001 & 0.481 \\
\hline
\end{tabular}

Based on table 6, the results of the two-way ANOVA analysis revealed that there was a significant interaction between Motivation and Quranic achievement in terms of age $\quad[F=1.452 ; p=$ $0.031]$, place of origin $[F=1.950 ; p=0.007]$ and vice versa in terms of parental income $[F=1.001 ; p$ $=0.481]$ and gender $[F=1.344 ; p=0.135]$.

\section{Discussion}

Teachers are responsible for instilling a sense of motivation in their students. Based on a study conducted by Noh (2014), he found that teachers' methods closely relate to a student's success in 
memorizing the Quran. Teachers need to instil a sense of urgency in the students to memorize the 30 Juzu' of the Quran with utmost excellence. Not only in the class in front of a teacher (tasmi '), but also in examinations.

Teachers need to explain to students why they need to recite the Quran and why they need to excel in their memorization. This can be done in two ways as described by Saleh (2014), which are intrinsic motivation and extrinsic motivation. Before the teacher starts the recitation class, they begin the session by reading motivational words or quotes about the benefits of reciting the Quran, for example, 40 hadith on the benefits of reciting the Quran. In terms of extrinsic motivation, it can be developed by creating an excellent environment through support programs such as displaying excellent student records in the classroom, rewarding students with speeches or by rewards, give gifts for their successes, giving them VIP seats during events, give certain allowances based on the achievements and the number of Juzu' that they have memorized and so on.

\section{Conclusion}

This research shows that Motivation has a positive and significant relationship towards Quranic memorisation achievements. The higher a student's level of Motivation, the higher his or her level of achievement in Quranic memorisation. Conversely, the lower a student's level of Motivation, the lower the student's level of achievement in Quranic memorisation.

In this research, it has focused only on students using the tahfiz integrated curriculum syllabus which is based for secondary schools that combines academic subjects and the memorisation of 30 juzu' of the Quran. This research does not involve schools that only run Quranic memorisation programmes or memorisation programmes at the Diploma level. Therefore, it is suggested that in future research, tahfiz schools without academic subjects or Diploma level programs are to also be involved, so that the results will be more interesting and the information will be more extensive.

\section{Acknowledgement}

This study is the result of a Phd project paper conducted by Mohd Saleh Bin Ramli involving 254 Tahfiz School students of the State of Pahang, Malaysia.

\section{Corresponding Author}

Name : : Associate Professor Dr Syed Sofian Syed Salim

Affiliation : Sultan Idris Education University

Country : Malaysia

Email ID : sofian@fpm.upsi.edu.my

Address : Faculty of Education and Human Development, Sultan Idris Education University 35900 Tanjong Malim, Perak

\section{References}

Ahmad, R. A. H., Iza, F., Mohd, P., Abdul, R. A. G., \& Misnan, J. (2017). Faktor Motivasi Dalam Amalan Pembelajaran Hafazan Al-Quran. Jurnal Perspektif: Special Issue, 1(1), pp. 13-20.

Arif, K. (2013). Hubungan Antara Motivasi Berprestasi Dan Flow Akademik. Jurnal Ilmiah Mahasiswa Universitas Surabaya. 2(1), pp. 1-12.

Azmil, H., Abdul H. T., \& Misnan, J. (2013). Latar Belakang Guru Tahfiz Dan Amalan Kaedah. Journal Of Islamic Education, 1(1), pp. 28-39.

Daud, F. (2012). Pengaruh Kecerdasan Emosional ( EQ ) Dan Motivasi Belajar Terhadap Hasil Belajar 
INTERNATIONAL JOURNAL OF ACADEMIC RESEARCH IN BUSINESS AND SOCIAL SCIENCES

Vol. 10, No. 5, May, 2020, E-ISSN: 2222-6990 @ 2020 HRMARS

Biologi Siswa SMA 3 Negeri Kota Palopo. Jurnal Pendidikan Dan Pembelajaran. 19 (2), pp. 243 255.

Khalid, A. D. (2016). Kaedah Pentaksiran Dalam Pendidikan Tahfiz: Ke Arah Melahirkan Huffaz Berkualiti Tinggi. Memperkasa Generasi Penghafaz al-Quran. Darul Quran Jakim. pp. 72-75.

Khazriyati, S. (2019). Heat Maps And Scan Paths: Qualitative Eye-Tracking Evidence On How The Qur'an Is Memorized Through Reading. Journal of Nusantara Studies 4(2), pp. 318-334.

Minhayati, S. (2014). Pengaruh Motivasi, Faktor Keluarga, Lingkungan Kampus Dan Aktif Berorganisasi Terhadap Prestasi Akademik, Jurnal Phenomenom 4(2), pp. 109-141.

Noh, A. C. H. E. (2014). Kaedah Pembelajaran Tahfiz Dan Hubungannya Dengan Pencapaian Hafazan Pelajar. Journal Of Al-Quran and Tarbiyyah, 1(1), pp. 9-16.

Nor, M. M. D., Mokmin, B. (2015). Perbandingan Kaedah Hafazan Al-Quran. Proceeding of the Social Sciences Research ICSSR 2014, pp. 827-834.

Norizah, T. (2014). Peningkatan Kemahiran Menghafaz Surah Dan Doa Kanak-Kanak Prasekolah Melalui Pendekatan Berasaskan Teori Kecerdasan Pelbagai. The Online Journal of Islamic Education, 2(1), pp. 114-129.

Purwanto, E. (2014). Model Motivasi Trisula: Sintesis Baru Teori Motivasi Berprestasi. Jurnal Psikologi. 41(2) pp. $218-228$. 